\title{
Bioefficacy of Different Miticides and Botanicals against Field Abundance Attacking Host Mite, Tetranychus cinnabarinus (Boisd) on Okra
}

\author{
P. R. Kale*, D. B. Pawar and S. A. Mane \\ Department of Entomology, PGI, MPKV, Rahuri-413 722, Maharashtra, India \\ *Corresponding author
}

\section{A B S T R A C T}

Keywords

Bioefficacy, selective miticides, field prevailing predatory mites on okra

Article Info

Accepted:

12 May 2021

Available Online:

10 June 2021
Bio efficacy of six newer and selective miticides / insecticides, dicofol (standard check), abamectin (treated check) along with botanicals and biopesticides viz., azadirachtin and lecanicilium lecani were studied against Tetranichus cinnabarinus on okra crop during summer, 2015. Two rounds of subsequent foliar applications were given at an interval of two weeks. Observations on Red spider mite were recorded at 3, 5, 7 and 14 DAT. Mean pre-treatment count of 30.96 to 31.93 mites / leaf/ sq.cm. The plots treated with abamectin $1.9 \mathrm{EC}$ at $0.00076 \%$ showed the lowest of 1.06 mites per leaf per sq. $\mathrm{cm}$. and was proved to be the most promising treatment and it was at par with chlorfenapyr $10 \mathrm{SC}$ at $0.01 \%$ (1.31 mites), fenazaquin $10 \mathrm{EC}$ at $0.037 \%$ (1.45 mites) and bifenazate $50 \mathrm{WP}$ at $0.037 \%$ (1.67 mites). The mite population in Lecanicillium lecanii at $1.15 \%$ was recorded 10.02 mites and it was at par with azadirachtin at $300 \mathrm{ppm} @ 5 \mathrm{ml} / \mathrm{lit}$. (11.18 mites) and both the treatments were superior over untreated control. However, Lecanicilium lecanii and azadirachtin were not superior over chemical treatment. Whereas, they were superior over untreated check in reducing the number of mites per leaf per sq. $\mathrm{cm}$.

\section{Introduction}

Okra (Abelmoschus esculentus L.) is important vegetable crop widely cultivated round the year in India. The crop is attacked by a number of pests and diseases. Among them, red spider mite, Tetranychus cinnabarinus (Boisd) is a polyphagous species and is now a serious menace causing yield losses up to the tune of 7 to 48 per cent (Anonymous, 1996).
The mite colony comprises of nymph and adults, which feed on ventral leaf surface and form silken webs for protecting themselves from natural enemies and pesticides. In case of heavy infestation, shedding of leaves occurs and affects normal growth that lowers down the fruit bearing capacity. Development of more number of generations within a short period especially under favorable conditions, very high rate of reproduction and ability to 
develop cross resistance to various pesticides quickly have made the task of mite management more difficult.

Chemical control of phytophagous mites mostly relies upon three major chemical categories, viz., non-selective insecticides/ miticides (e.g. dicofol), and miticides with some degree of selectivity (e.g. formamidin) and more specific miticides (e.g. bifenazate, fenazaquin, abamectin). Now a days, emphasis is being given on low risk miticides that are active at low field dosages having controlled action span and least non-target effect.

\section{Materials and Methods}

The present studies were undertaken in a summer season at the Research Farm of Department of Agricultural Entomology, Post Graduate Institute, Mahatma Phule Krishi Vidyapeeth, Rahuri, Dist. Ahmednagar (Maharashtra state)

The seeds of okra variety: Phule Utkarsha was provided by Department of Agricultural Entomology, M.P.K.V., Rahuri. Miticides evaluated in the present investigations were obtained from the respective manufacturers and local market. The treatment details viz, common name, trade name, a.i. /ha and concentrations of spray solutions are given in Table

Manually operated knapsack sprayer (Aspee make) with hollow cone nozzle was used for spraying of miticides on okra crop.

\section{Raising of okra crop}

Ridges and furrows of $4.80 \times 3.30 \mathrm{~m}$. size were prepared. FYM @ 10 tons/ ha was added at the time of land preparation. Seeds of variety, Phule Utkarsha were dibbled at $45 \mathrm{x}$ $15 \mathrm{~cm}$ spacing. Two seeds were dibbled at 2.0$2.5 \mathrm{~cm}$ deep per hill. After 7 days of sowing, thinning and gap filling was done to maintain one plant per hill per spot. Recommended dose of fertilizers @ 100:50:50 (N: P: K) kg/ ha were given as per the package of practices of crop cultivation, except the plant protection measures.

\section{Application of miticides}

Test treatments were applied as foliar sprays, initiating first application at the ETL of mites, synchronizing with the evenly distributed mite infestation in field. The second subsequent application was given 14th days after the first application at ETL. Spraying was carried out at early morning session and during the spray application care was undertaken to cover the maximum plant canopy thoroughly and to avoid the drift. In all, two rounds of subsequent foliar applications were given by using manually operated knapsack sprayer, keeping spray fluid discharge rate of $500 \mathrm{l} / \mathrm{ha}$.

\section{Method of recording observations}

Five plants were randomly selected from each of the experimental plots, excluding the border rows. On every pre-selected plant, three fairly uniform leaves, each from top, middle and bottom canopy were selected. Pre-treatment count was recorded to assess the uniformity of mite occurrence and sufficient mite load to cause enough injury to crop. The mite population was counted on both, upper and lower surfaces of each of the leaves, with 1 sq. $\mathrm{cm}$. area by using magnifying lens $(10 \mathrm{X})$. Pre count was recorded before the treatment and post count at 3rd, 5th, 7th and 14th days after the treatment (DAT) during the early day hours.

\section{Effect of test miticides on yield of okra fruits}

Marketable yield of okra fruits was recorded at each picking and the sum was counted in $\mathrm{t} /$ ha. Thereafter, the per cent increase of marketable okra yield in the treatment over the untreated check was computed. 


\section{Statistical analysis}

Data on surviving mite population were transformed to square root value $[(n+0.5) 1 / 2]$ to stabilize the heterogeneous variances.

The transformed data for the respective evaluation dates were analyzed as a randomized block design (RBD). The means of three replicates were compared by using the standard error (S.E.) and critical difference (C.D.) at 5 per cent to decide the significance of individual treatment effect. (Panse and Sukhatme, 1985).

The yield data were subjected to statistical analysis. Finally, an incremental cost benefit ratio (ICBR) of each treatment was worked out

\section{Results and Discussion}

The results of the investigation carried out on the bioefficacy of miticides against okra mite, $T$. cinnabarinus under field conditions was judged on the basis of mite population on five randomly selected plant and three leaves of the okra in each treatment one day before (precount) and $3^{\text {rd }}, 5^{\text {th }}, 7^{\text {th }}$ and $14^{\text {th }}$ days after miticidal application (post count). Statistical analysis of data collected from the field trials on surviving population

\section{Population of okra mite before spraying}

The data on number of mites recorded one day before the first spraying. The pre-count observations indicated that the average number of mites one day before the first spraying ranged between 30.96 to 31.93/leaf/sq.cm. and were statistically nonsignificant at $5 \%$ level of significance, suggesting that the population of mites on okra was uniform in field.
Effect of miticides against mite after First spray on okra

\section{Three days after first spray}

It is evident from the data that average number of mites at three days after first spraying varied from 1.50 to 31.01 in various treatments. All the miticidal treatments were found to be significantly superior over untreated control in reducing the mite populations. The plots treated with abamectin $1.9 \mathrm{EC}$ at $0.00076 \%$ showed the lowest mites, (1.50 per leaf per sq. cm.) and was proved to be the most promising treatment and it was at par with chlorfenapyr $10 \mathrm{SC}$ at $0.01 \%(2.12$ mites), fenazaquin $10 \mathrm{EC}$ at $0.01 \% \quad(2.17$ mites) and bifenazate 50 WP at $0.037 \%$ (2.22 mites). The mite population in Lecanicillium lecanii at $1.15 \%$ was recorded to 15.27 mites and it was at par with azadirachtin (17.33 mites) and both the treatments were superior over untreated control. However, Lecanicilium lecanii and azadirachtin were not superior over chemical treatments.

\section{Five days after spray}

It is evident from the data that average number of mites at five days after first spray varied from 0.32 to 31.16 in various treatments. All the miticidal treatments were found to be significantly superior over untreated control in reducing the mite populations.

The plots treated with abamectin 1.9 EC at $0.00076 \%$ showed the lowest of 0.32 mites per leaf per sq. $\mathrm{cm}$. and was proved to be the most promising treatment. However, it was at par with chlorfenapyr $10 \mathrm{SC}$ at $0.01 \% \quad(0.46$ mites), fenazaquin $10 \mathrm{EC}$ at $0.01 \% \quad(0.77$ mites) and bifenazate $50 \mathrm{WP}$ at $0.037 \%(0.87$ mites). 
The mite population in Lecanicillium lecanii $1.15 \%$ was recorded 6.65 mites It was at par with Azadirachtin (8.17mites) and both the treatments were superior over untreated control. Whereas, Lecanicillium lecanii and azadirachtin were not superior over chemical treatment.

\section{Seven days after spray}

All the miticidal treatments were found to be significantly superior over untreated control in reducing the mite populations.

The plots treated with abamectin 1.9 EC at $0.00076 \%$ showed the lowest of 0.21 mites per leaf per sq. $\mathrm{cm}$. and was proved to be the most promising treatment and it was at par with chlorfenapyr $10 \mathrm{SC}$ at $0.01 \%$ (0.28 mites), fenazaquin $10 \mathrm{EC}$ at $0.01 \%$ (0.33 mites) and bifenazate $50 \mathrm{WP}$ at $0.037 \%$ (0.56 mites).

The mite population in Lecanicillium lecanii $1.15 \%$ was recorded 5.78 mites and it was at par with azadirachtin (6.42 mites) and both the treatment was superior over untreated control.

\section{Fourteen days after spray}

The plots treated with abamectin 1.9 EC at $0.00076 \%$ showed the lowest of 2.60 mites per leaf per sq. $\mathrm{cm}$. and was proved to be the most promising treatment and it was at par with chlorfenapyr $10 \mathrm{SC}$ at $0.01 \%$ (2.86 mites), fenazaquin $10 \mathrm{EC}$ at $0.01 \%$ (2.84 mites) and bifenazate $50 \mathrm{WP}$ at $0.037 \%$ (3.44 mites).

The mite population in Lecanicillium lecanii at $1.15 \%$ was recorded 13.39 mites and it was at par with azadirachtin at 300ppm @ 5ml/lit. (13.82 mites) and both the treatments were superior over untreated control
Effect of miticides against mite after second spray on okra

\section{Three days after spray}

It is evident from the data that average number of mites at three days after second spray varied from 1.25 to 31.68 in various treatments. All the miticidal treatments were found to be significantly superior over untreated control in reducing the mite populations. The plots treated with abamectin $1.9 \mathrm{EC}$ at $0.00076 \%$ showed the lowest of 1.25 mites per leaf per sq. $\mathrm{cm}$. and was proved to be the most promising treatment and it was at par with chlorfenapyr $10 \mathrm{SC}$ at $0.01 \%$ (1.64 mites), fenazaquin $10 \mathrm{EC}$ at $0.01 \% \quad(1.97$ mites) and bifenazate 50 WP at $0.037 \%$ (2.15 mites). The mite population in Lecanicillium lecanii at $1.15 \%$ was recorded 9.80 mites and it was at par with azadirachtin (11.72 mites) and both the treatment was superior over untreated control.

\section{Five days after spray}

All the miticidal treatments were found to be significantly superior over untreated control in reducing the mite populations. The plots treated with abamectin $1.9 \mathrm{EC}$ at $0.00076 \%$ showed the lowest of 0.21 mites incidence by 5.80 mites as against untreated control (10.33 mites). per leaf per sq. cm. and was proved to be the most promising treatment and it was at par with chlorfenapyr $10 \mathrm{SC}$ at $0.01 \%(0.37$ mites), fenazaquin $10 \mathrm{EC}$ at $0.01 \% \quad(0.46$ mites) and bifenazate $50 \mathrm{WP}$ at $0.037 \%(0.57$ mites). The mite population in Lecanicillium lecanii at $1.15 \%$ was recorded 8.56 mites and it was at par with azadirachtin @ 5ml/lit. (9.80 mites) and both the treatments were superior over untreated control. 
Table.1 Treatment details for field trial on okra

\begin{tabular}{|c|c|c|c|c|}
\hline Treatment & Chemical Name & Trade Name & Conc. (\%) & Dose/ha \\
\hline $\mathbf{T}_{\mathbf{1}}$ & Bifenazate & Floramite & 0.037 & $375 \mathrm{ml}$ \\
\hline $\mathbf{T}_{\mathbf{2}}$ & Fenazaquin & Magister & 0.01 & $500 \mathrm{ml}$ \\
\hline $\mathbf{T}_{\mathbf{3}}$ & Thiamethoxam & Actara & 0.01 & $250 \mathrm{gm}$ \\
\hline $\mathbf{T}_{\mathbf{4}}$ & Chlorfenapyr & Intrepid & 0.01 & $500 \mathrm{ml}$ \\
\hline $\mathbf{T}_{\mathbf{5}}$ & Propargite & Omite & 0.057 & $500 \mathrm{ml}$ \\
\hline $\mathbf{T}_{\mathbf{6}}$ & Lecanicillium lecanii & Phule bugicide & 1.15 & $2500 \mathrm{gm}$ \\
\hline $\mathbf{T}_{\mathbf{7}}$ & Profenophos+ Wettable & Curacron + & $0.05+0.20$ & $500 \mathrm{ml}$ \\
\hline & Sulphur & sulfex & & $+1000 \mathrm{gm}$ \\
\hline $\mathbf{T}_{\mathbf{8}}$ & Azadirechtin & Achook & $300 \mathrm{ppm}$ & $2500 \mathrm{ml}$ \\
\hline $\mathbf{T}_{\mathbf{9}}$ & Abamectin & Vertimec & 0.00076 & $200 \mathrm{ml}$ \\
\hline $\mathbf{T}_{\mathbf{1 0}}$ & Dicofol & Kelthane & 0.1 & $500 \mathrm{ml}$ \\
\hline $\mathbf{T}_{\mathbf{1 1}}$ & Untreated check & - & - & $500 \mathrm{ml}$ \\
\hline
\end{tabular}

Table.2 Field bioefficacy of miticides against Tetranychus cinnabarinus on okra after first spray

\begin{tabular}{|c|c|c|c|c|c|c|}
\hline \multirow{2}{*}{ Treatments } & \multicolumn{7}{|c|}{ Mean number of mites/ leaf/sq.cm. } \\
\cline { 2 - 7 } & $\begin{array}{c}\text { Pre- } \\
\text { count }\end{array}$ & 3 DAT & 5 DAT & 7 DAT & 14 DAT & Mean \\
\hline Bifenazate (0.037\%) & 31.33 & 2.22 & 0.87 & 0.56 & 3.44 & 1.62 \\
& $(5.64)$ & $(1.65)$ & $(1.17)$ & $(1.03)$ & $(1.98$ & $(1.42)$ \\
\hline Fenazaquin (0.01\%) & 31.58 & 2.17 & 0.77 & 0.33 & 2.84 & 1.48 \\
& $(5.66)$ & $(1.63)$ & $(1.13)$ & $(0.90)$ & $(1.83)$ & $(1.36)$ \\
\hline Thiamethoxam (0.01\%) & 31.03 & 7.02 & 4.08 & 2.42 & 6.87 & 4.89 \\
& $(5.61)$ & $(2.74)$ & $(2.13)$ & $(1.71)$ & $(2.71)$ & $(2.28)$ \\
\hline Chlorfenapyr (0.01\%) & 31.59 & 2.12 & 0.46 & 0.28 & 2.86 & 1.29 \\
& $(5.66)$ & $(1.61)$ & $(0.97)$ & $(0.88)$ & $(1.79)$ & $(1.28)$ \\
\hline Propargite (0.057\%) & 31.67 & 8.12 & 4.99 & 3.19 & 7.94 & 5.82 \\
& $(5.67)$ & $(2.93)$ & $(2.34)$ & $(1.92)$ & $(2.91)$ & $(2.48)$ \\
\hline Lecanicillium lecanii & 31.38 & 15.27 & 6.65 & 5.78 & 13.39 & 9.62 \\
(1.15\%) & $(5.65)$ & $(3.97)$ & $(2.67)$ & $(2.49)$ & $(3.72)$ & $(3.12)$ \\
\hline Profenophos+ Wettable & 31.93 & 7.26 & 4.72 & 2.91 & 7.25 & 5.28 \\
Sulphur (0.05+0.20\%) & $(5.69)$ & $(2.79)$ & $(2.29)$ & $(1.85)$ & $(2.78)$ & $(2.38)$ \\
\hline Azadirachtin (300ppm) & 31.63 & 17.33 & 8.17 & 6.42 & 13.82 & 10.88 \\
& $(5.67)$ & $(4.22)$ & $(2.94)$ & $(2.62)$ & $(3.78)$ & $(3.31)$ \\
\hline Abamectin (0.00076\%) & 31.68 & 1.50 & 0.32 & 0.21 & 2.60 & 1.05 \\
& $(5.67)$ & $(1.41)$ & $(0.91)$ & $(0.84)$ & $(1.73)$ & $(1.19)$ \\
\hline Dicofol (0.1\%) & 31.55 & 3.68 & 1.34 & 0.83 & 8.96 & 2.59 \\
& $(5.66)$ & $(2.03)$ & $(1.34)$ & $(1.13)$ & $(3.08)$ & $(1.68)$ \\
\hline Untreated check & 30.96 & 31.01 & 31.16 & 31.31 & 31.56 & 31.24 \\
& $(5.61)$ & $(5.61)$ & $(5.63)$ & $(5.64)$ & $(5.66)$ & $(5.63)$ \\
\hline S. E. \pm & 0.05 & 0.09 & 0.09 & 0.08 & 0.11 & 0.09 \\
\hline C. D. at 5\% & N.S & 0.27 & 0.29 & 0.25 & 0.33 & 0.28 \\
\hline
\end{tabular}

Figures in the parentheses are $(\sqrt{x+0.5})$ transformations, DAT-Days after treatment 
Table.3 Field bioefficacy of miticides against $T$. cinnabarinus on Okra after second spray.

\begin{tabular}{|c|c|c|c|c|c|}
\hline \multirow[t]{2}{*}{ Treatments } & \multicolumn{5}{|c|}{ Mean number of mites/ leaf/sq.cm. } \\
\hline & 3 DAT & 5 DAT & 7 DAT & 14 DAT & Mean \\
\hline Bifenazate $(0.037 \%)$ & $\begin{array}{c}2.15 \\
(1.62)\end{array}$ & $\begin{array}{c}0.57 \\
(1.03)\end{array}$ & $\begin{array}{c}0.33 \\
(0.90)\end{array}$ & $\begin{array}{c}3.29 \\
(1.95)\end{array}$ & $\begin{array}{c}1.58 \\
(1.79)\end{array}$ \\
\hline Fenazaquin $(0.01 \%)$ & $\begin{array}{c}1.97 \\
(1.56)\end{array}$ & $\begin{array}{c}0.46 \\
(0.97)\end{array}$ & $\begin{array}{c}0.24 \\
(0.86)\end{array}$ & $\begin{array}{c}2.84 \\
(1.83)\end{array}$ & $\begin{array}{c}1.37 \\
(1.62)\end{array}$ \\
\hline Thiamethoxam $(0.01 \%)$ & $\begin{array}{c}6.61 \\
(2.65)\end{array}$ & $\begin{array}{c}1.64 \\
(1.45)\end{array}$ & $\begin{array}{c}1.70 \\
(1.46)\end{array}$ & $\begin{array}{c}7.57 \\
(2.83)\end{array}$ & $\begin{array}{c}4.38 \\
(3.32)\end{array}$ \\
\hline Chlorfenapyr $(0.01 \%)$ & $\begin{array}{c}1.64 \\
(1.45)\end{array}$ & $\begin{array}{c}0.37 \\
(0.93)\end{array}$ & $\begin{array}{c}0.18 \\
(0.83)\end{array}$ & $\begin{array}{c}2.60 \\
(1.75)\end{array}$ & $\begin{array}{c}1.19 \\
(1.52)\end{array}$ \\
\hline Propargite $(0.057 \%)$ & $\begin{array}{c}8.56 \\
(3.01)\end{array}$ & $\begin{array}{c}2.26 \\
(1.66)\end{array}$ & $\begin{array}{c}2.30 \\
(1.67)\end{array}$ & $\begin{array}{l}9.23 \\
(3.12)\end{array}$ & $\begin{array}{c}5.58 \\
(3.92)\end{array}$ \\
\hline $\begin{array}{c}\text { Lecanicillium lecanii } \\
(1.15 \%)\end{array}$ & $\begin{array}{c}9.80 \\
(3.21)\end{array}$ & $\begin{array}{c}8.56 \\
(3.01)\end{array}$ & $\begin{array}{c}8.42 \\
(2.99)\end{array}$ & $\begin{array}{l}12.32 \\
(3.57)\end{array}$ & $\begin{array}{c}9.77 \\
(5.47)\end{array}$ \\
\hline $\begin{array}{l}\text { Profenophos + Wettable } \\
\text { Sulphur }(0.05+0.20 \%)\end{array}$ & $\begin{array}{l}7.25 \\
(2.78)\end{array}$ & $\begin{array}{c}1.97 \\
(1.56)\end{array}$ & $\begin{array}{c}1.99 \\
(1.58)\end{array}$ & $\begin{array}{c}8.73 \\
(3.04)\end{array}$ & $\begin{array}{c}4.98 \\
(3.72)\end{array}$ \\
\hline Azadirachtin (300ppm) & $\begin{array}{l}11.72 \\
(3.48)\end{array}$ & $\begin{array}{c}9.80 \\
(3.21)\end{array}$ & $\begin{array}{c}9.50 \\
(3.16)\end{array}$ & $\begin{array}{l}12.72 \\
(3.63)\end{array}$ & $\begin{array}{l}10.93 \\
(5.68)\end{array}$ \\
\hline Abamectin $(0.00076 \%)$ & $\begin{array}{c}1.25 \\
(1.32)\end{array}$ & $\begin{array}{c}0.21 \\
(0.84)\end{array}$ & $\begin{array}{c}0.06 \\
(0.75)\end{array}$ & $\begin{array}{c}2.38 \\
(1.68)\end{array}$ & $\begin{array}{c}0.97 \\
(1.41)\end{array}$ \\
\hline $\operatorname{Dicofol}(0.1 \%)$ & $\begin{array}{c}3.27 \\
(1.92)\end{array}$ & $\begin{array}{c}0.83 \\
(1.13)\end{array}$ & $\begin{array}{c}0.60 \\
(1.05)\end{array}$ & $\begin{array}{c}9.36 \\
(3.14)\end{array}$ & $\begin{array}{c}3.51 \\
(3.67)\end{array}$ \\
\hline Untreated check & $\begin{array}{c}31.68 \\
(5.67)\end{array}$ & $\begin{array}{l}31.83 \\
(5.69)\end{array}$ & $\begin{array}{l}31.90 \\
(5.69)\end{array}$ & $\begin{array}{l}32.84 \\
(5.77)\end{array}$ & $\begin{array}{r}32.06 \\
(5.71)\end{array}$ \\
\hline S.E. \pm & 0.13 & 0.09 & 0.07 & 0.10 & 0.09 \\
\hline C. D. at $5 \%$ & 0.39 & 0.26 & 0.21 & 0.30 & 0.29 \\
\hline
\end{tabular}

$*$ Figures in the parentheses are $(\sqrt{x+0.5})$ transformations, DAT-Days after treatment 
Table.4 Overall field bioefficacy of miticides against Tetranychus cinnabarinus on okra

\begin{tabular}{|c|c|c|c|c|c|}
\hline \multirow{2}{*}{ Treatments } & \multicolumn{5}{|c|}{ Mean number of mites/ leaf/sq.cm. } \\
\cline { 2 - 6 } & 3 DAT & 5 DAT & 7 DAT & 14 DAT & Mean \\
\hline Bifenazate $(0.037 \%)$ & 2.18 & 0.72 & 0.44 & 3.36 & 1.67 \\
& $(1.63)$ & $(1.10)$ & $(0.96)$ & $(1.96)$ & $(1.41)$ \\
\hline Fenazaquin (0.01\%) & 2.07 & 0.61 & 0.28 & 2.84 & 1.45 \\
& $(1.59)$ & $(1.05)$ & $(0.88)$ & $(1.83)$ & $(1.33)$ \\
\hline Thiamethoxam (0.01\%) & 6.81 & 2.86 & 2.06 & 7.22 & 4.73 \\
& $(2.69)$ & $(1.79)$ & $(1.58)$ & $(2.77)$ & $(2.20)$ \\
\hline Chlorfenapyr (0.01\%) & 1.88 & 0.41 & 0.23 & 2.73 & 1.31 \\
& $(1.53)$ & $(0.95)$ & $(0.85)$ & $(1.77)$ & $(1.27)$ \\
\hline Propargite (0.057\%) & 8.34 & 3.62 & 2.74 & 8.58 & 5.82 \\
& $(2.97)$ & $(2.00)$ & $(1.79)$ & $(3.01)$ & $(2.44)$ \\
\hline Lecanicillium lecanii & 12.53 & 7.60 & 7.10 & 12.85 & 10.02 \\
(1.15\%) & $(3.59)$ & $(2.84)$ & $(2.74)$ & $(3.64)$ & $(3.20)$ \\
\hline Profenophos + Wettable & 7.25 & 3.34 & 2.45 & 7.99 & 5.25 \\
Sulphur (0.05+0.20\%) & $(2.78)$ & $(1.92)$ & $(1.71)$ & $(2.91)$ & $(2.33)$ \\
\hline Azadirachtin(300 ppm) & 14.52 & 8.98 & 7.96 & 13.27 & 11.18 \\
& $(3.85)$ & $(3.07)$ & $(2.89)$ & $(3.70)$ & $(3.37)$ \\
\hline Abamectin (0.00076\%) & 1.37 & 0.26 & 0.13 & 2.49 & 1.06 \\
& $(1.36)$ & $(0.87)$ & $(0.79)$ & $(1.70)$ & $(1.18)$ \\
\hline Dicofol (0.1\%) & 3.47 & 1.08 & 0.71 & 9.16 & 3.60 \\
& $(1.97)$ & $(1.23)$ & $(1.09)$ & $(3.11)$ & $(1.85)$ \\
\hline Untreated check & 31.34 & 31.49 & 31.60 & 32.20 & 31.65 \\
& $(5.64)$ & $(5.66)$ & $(5.66)$ & $(5.71)$ & $(5.66)$ \\
\hline C. D. at 5 \pm & 0.11 & 0.09 & 0.07 & 0.10 & 0.09 \\
\hline & 0.33 & 0.27 & 0.23 & 0.31 & 0.28 \\
\hline
\end{tabular}

Figures in the parentheses are $(\sqrt{x+0.5})$ transformations, DAT-Days after treatment

\section{Seven days after spray}

It is evident from the data that average number of mites at seven days after second spray varied from 0.06 to 31.90 in various treatments. All the miticidal treatments were found to be significantly superior over untreated control in reducing the mite populations. The plots treated with abamectin $1.9 \mathrm{EC}$ at $0.00076 \%$ showed the lowest of 0.06 mites per leaf per sq. $\mathrm{cm}$. and was proved to be the most promising treatment and it was at par with chlorfenapyr $10 \mathrm{SC}$ at $0.01 \%(0.18$ mites), fenazaquin $10 \mathrm{EC}$ at $0.01 \% \quad(0.24$ mites) and bifenazate $50 \mathrm{WP}$ at $0.037 \%(0.33$ mites). The mite population in Lecanicillium lecanii at $1.15 \%$ was recorded 8.42 mites and it was at par with azadirachtin at 300 ppm @ 5ml/lit. (9.50 mites) and both the treatments were superior over untreated control. However, Lecanicilium lecanii and azadirachtin were not superior over chemical treatment. They were superior over untreated check.

\section{Fourteen days after spray}

It is evident from the data that average number of mites at fourteen days after second spray varied from 2.38 to 32.84 in various 
treatments. All the miticidal treatments were found to be significantly superior over untreated control in reducing the mite populations. The plots treated with abamectin $1.9 \mathrm{EC}$ at $0.00076 \%$ showed the lowest of 2.38 mites per leaf per sq. $\mathrm{cm}$. and was proved to be the most promising treatment and it was at par with chlorfenapyr $10 \mathrm{SC}$ at $0.01 \%(2.60$ mites), fenazaquin $10 \mathrm{EC}$ at $0.01 \%(2.84$ mites) and bifenazate 50 WP at $0.037 \%$ (3.29 mites). The mite population in Lecanicillium lecanii at $1.15 \%$ was recorded 12.32 mites and it was at par with azadirachtin at 300 ppm @ $5 \mathrm{ml} / \mathrm{lit}$.(12.72 mites) and both the treatments were superior over untreated control.

Overall cumulative effect of different miticides on population of $T$. cinnabarinus on okra (Average of two sprays)

The data on cumulative per cent number of survival population of mites in different miticides after first and second sprays revealed that all the miticidal treatments were found to be significantly superior over untreated control in reducing the mite populations. The plots treated with abamectin 1.9 EC at $0.00076 \%$ showed the lowest of 1.06 mites per leaf per sq. $\mathrm{cm}$. and was proved to be the most promising treatment and it was at par with chlorfenapyr $10 \mathrm{SC}$ at $0.01 \%$ (1.31 mites), fenazaquin $10 \mathrm{EC}$ at $0.037 \%$ (1.45 mites) and bifenazate $50 \mathrm{WP}$ at $0.037 \%$ (1.67 mites). The mite population in Lecanicillium lecanii at $1.15 \%$ was recorded 10.02 mites and it was at par with azadirachtin at $300 \mathrm{ppm} @ 5 \mathrm{ml} / \mathrm{lit}$. (11.18 mites) and both the treatments were superior over untreated control. However, Lecanicilium lecanii and azadirachtin were not superior over chemical treatment. Whereas, they were superior over untreated check in reducing the number of mites per leaf per sq. $\mathrm{cm}$. The remaining treatments in the order of efficacy were dicofol 18.5 EC, thiomethoxam $25 \mathrm{WG}$, profenophos $50 \mathrm{EC}+$ wettable sulphur $50 \mathrm{WP}$ and propargite $57 \mathrm{EC}$ which have noted 3.60, 4.73 and 5.25 and 5.82 mites/leaves/sq.cm. respectively

During the entire period of investigations, in comparison with the untreated check, all the treatments under the studies were found to be promising in suppressing the population of the host mite.

Amongst, abamectin was found the most promising treatment. The results are in confirmation with that reported by Brits and Vickers (1990) and Venugopal et al., (2003) against $T$. cinnabarinus on cotton and okra respectively. Kumar and Singh (2003 \& 2004) against $T$. macfarlanei on pumpkin and Dutta et al., (2012) against $T$. urticae on brinjal.

Similarly, chlorfenapyr, fenazaquin and bifenazate were at par with abamectin. The results in respect of chlorfenapyr are in substantiated with the findings reported by Vasquez and Ceballos (2009) on tomato, Muhammad et al., (2012) and Esteves (2013) against $T$. urticae. Similarly, the effectiveness of fenazaquin has been reported by Dhar et al., (2000), Kavitha et al., (2006) and Sangeetha and Ramaraju (2013) against T. urticae on okra. The results in respect to bifenazate are in line with that reported by Rani and Sridhar (2005) on rose, Labanowsaka (2007) and Vostrel (2011) against $T$. urticae on strawberry and hope respectively.

Dicofol was found to be the next best treatment. The results are in confirmatory with that of Patel et al., (1993) and Sugeetha (1998) against $T$. macfarlanei. However, its field efficacy exhibited up to 15 days and the findings are similar with that of reported by Siddiqui and Singh (2006) and Jasmine et al., (2008) against $T$. urticae on rose. Nakmura and Sasaki (2004) pointed out that dicofol did not show consistent bioefficacy against on cucumber. 


\section{References}

Anonymous, 1996. Progress Report-AICRP (Agril. Acarology): V Group Meeting. Nov.6-7, Ludhiana.

Brits, J. A. and Vickers, A. R. 1990. Efficacy of difenthiuron against red spider mite on cotton in South Africa. J. Entomol. Soc. South Africa, 53(2): 159-163.

Dhar, T., Dey, P. K. and Sarkar, P. K. 2000. Influence of abiotic factor on population build-up of red spider mite Tetranychus urticae on okra and evaluation of some new pesticides for their control. Pestology, 24(9): 34-37.

Dutta, N. K., Alam, S. N., Uddin, M. K., Mahmudunnabi, M. and Khatun, M. F. 2012. Population abundance of red spidermite in different vegetables along with its spatial distribution and chemical control in brinjal (Solanum melongena L.). Bangladesh J. Agric. Res., 37(3): 399-404.

Esteves, A. B., Oliveira, J. V. and Matos, C. C. 2013. Residual efficacy of synthetic acaricides and natural products for Tetranychus urticae Koch on cotton. Revista Brasileira de Ciencias Agrarias, 8(4): 583-588.

Jasmine, R. S., Kuttalam, S. and Stanley, J. 2008. Bio-efficacy and safety of abamectin against two spotted spider mite and its predatory mite on rose. Annl. Pl. Protec. Sci., 16(1): 46-52.

Kavitha, J., Kuttalam, S. and Chandrasekaran, S. 2006. Evaluation of spiromesifen 240 SC against chilli mite Polyphagotarsonemus latus (Banks) Annl. Pl. Protec. Sci., 14(1): 71-73.

Kumar, S. and Singh, R. N. 2003.Management of spider mite, Tetranychus macfarlanei Baker and Pritchard on pumpkin, Cucurbita moschata Dutch.Resist. Pest Mgmt., 13(1): 3033.

Kumar, S. and Singh, R. N. 2004. Influence of certain acaricides and botanicals against spider mite on pumpkin, Cucurbita moschata Dutch. J. Appl. Zool. Res., 15(2): 145-148.

Labanowska, B. H. 2007. The suitability of mixtures of amitraz + clofentezine and propargite and hexythiazox and other acaricides for the control of two spotted spider mite Tetranychus urticae Koch. on strawberry, Zeszyty Naukowe Instytutu Sadownictwa Kwiaciarstwa wSkierniewicach, (2): 65-75.

Muhammad, A. B., Gogi, M. H., Khan, M. D. and Ali, M. A. 2012. Evaluation of some acaricides against two spotted spider mites, Tetranychus urticae Koch. (Acari: Tetranychidae) on cotton crop under laboratory and field conditions. 34(2): 125-129.

Nakamura, A. and Sasaki, M. 2004. Effects of acaricides on two-spotted spider mite, Tetranychus urticae Koch, collected from cucumber in Fuku. Annl. Repo. Soci. Pl. Protec. North Japan, (55): 207-210.

Panse, V. G. and Sukhatme, P. V. 1985. Statistical methods for agricultural workers, II ${ }^{\text {nd }}$ enlarged Edition. I.C.A.R., New Delhi, PP-135-136.

Patel, C. B., Rai, A. B., Patel, M. B., Patel, A. J. and Shah, A. A 1993. Acaricidal tests of botanical pesticides in comparison to conventional acaricides / pesticides against red spider mites (Acari: Tetranychidae) on okra, brinjal and Indian bean. Ind. J. Entomol., 55(2): 184-190.

Rani, B. J. and Sridhar, V. 2005. Bio-efficacy of a new acaricide, bifenazate against the two spotted spider-mite, Tetranychus urticae Koch. on rose under protected cultivation. J. Orn. Horti., 8(1): 59-61.

Sangeetha, S. and Ramaraju, K. 2013. Relative toxicity of fenazaquin against 
two-spotted spider mite on okra.Int. J. Veg. Sci., 19(3): 282-293.

Siddiqui, I. and Singh, J. 2006. Efficacy of insecticides/ acaricides against red spider mite Tetranychus urticae Koch. Env. Ecol., 24(2): 480-481.

Sugeetha, G. 1998. Studies on the spider mite: Tetranychus macfarlanei Baker and Pritchard (Acari: Tetranychidae) infesting okra (Abelmoschus esculentus (L.) Moench). M. Sc. (Agri.) Thesis, Univ. Agri. Sci., Bangalore.
Vasquez, C. and Ceballos, M. C. 2009. Efficacy of chlorfenapyr and abamectin to control of Tetranychus urticae Koch (Acari: Tetranychidae), 27(1): 23-28.

Venugopal, V., Govardhan, N. V. and Prasad, P. R. 2003. Evaluation of new acaricides against red spider mite, Tetranychus cinnabarinus (Boisduval) on okra. Pestology, 27(3): 29-34.

Vostrel, J. C. 2011. Methodological recommendations for protection of hops from pests,84(4): 38-42.

\section{How to cite this article:}

Kale, P. R., D. B. Pawar and Mane, S. A. 2021. Bioefficacy of Different Miticides and Botanicals against Field Abundance Attacking Host Mite, Tetranychus cinnabarinus (Boisd) on Okra. Int.J.Curr.Microbiol.App.Sci. 10(06): 257-266.

doi: https://doi.org/10.20546/ijcmas.2021.1006.027 